\title{
A Survey of United States Tree Care Companies: Part I - Safety Training and Fatal Accidents
}

\author{
John Ball and Shane Vosberg
}

\begin{abstract}
Tree work has a high accident rate compared to many other occupations. News accounts of recent accidents can be easily accessed through the internet, though this may not provide a true picture of the number and types of accidents occurring. U.S. government bureaus and agencies have produced reports citing the number and circumstances of fatal accidents in the profession. The government's information is obtained from many sources and may not accurately identify types or frequency of these accidents. A survey of the accidents and safety training among tree care companies was conducted using a mail questionnaire based on the Tailored Design Method. The company managers responding to the survey overwhelming identified having trained field workers as very important yet only about two-thirds of their companies conducted any training. The training most often conducted was on aerial lifts, chain saws, and chipper, which was provided by company employees in a field setting. Driver's training was not part of a formal safety program for most of the companies. Aerial rescue was practiced by about one-fourth of the surveyed companies. The most common fatal accidents involved contact with an electrical conductor followed by being struck by a falling limb. The relative number of fatal accidents by event or exposure in this survey was similar to that identified by two federal government reports on fatal accident in the field.

Key Words. Arboricultural Accidents; Arboricultural Accident Survey; Safety Training; Tailored Design Method; Tree Care Industry Accidents.
\end{abstract}

Arboriculture has always been regarded as a high-risk profession due to a work environment that encompasses working aloft and manipulating heavy loads while using power equipment. It has also been described as a profession having peculiar risks, ones associated with the unique skills and equipment needed to perform this work (Blair 1989). Unfortunately, tree work has also been regarded as a profession with a poor safety record (McGarry 1962; Ryan and Ertel 1988).

News accounts of tree care industry accidents are readily available from the internet and describe a wide range of situations and injuries, a reflection of the complexity of the work. However there is little data quantifying tree worker accidents, past or present. Kiplinger (1938) listed 33 different accidents that he either witnessed or investigated, noting a large number were due to "top men" dropping limbs before being certain the drop zone was clear of people. Kiplinger identified a number of other accidents that were common to the time period, including contact with energized conductors and workers being hit by passing traffic, but he provided little information on frequency of these events. Karl Kuemmerling (1948) surveyed tree worker accidents in the state of Ohio between 1944 and 1946. He concluded that falls were the most common type of accident followed by contact with an electrical conductor and being struck by a falling limb. McGarry (1962) in a survey of accidents occurring in the Bartlett Tree Expert Company observed that $75 \%$ of the accidents could be placed in one of eight categories: falls to a lower level, falls to the same level, caught in-on-or between something, striking against something, being struck by something, over-exerting, contact with an electrical conductor, and poisoning from chemicals or plants. Regardless of the circumstances, the tree care industry accident rate in terms of lost time, injuries per hours of exposure was four to five times higher than all-industry averages at the time (Chadwick 1972).

The federal government has tracked accidents in the tree care profession and reported these findings in publications through the National Institute for Occupational Safety and Health (NIOSH), a part of the Centers for Disease Control and Prevention (CDC). An NIOSH Alert (1992) on tree care industry accidents pointed out that approximately 20 tree workers were killed each year with the two leading causes being electrocution and falls. The publication concludes that tree workers and their employers lacked training and may be unaware of the risks in this field. A 1996 report (Market Update 1996) noted 40 fatalities the previous year in the tree care profession with 13 each occurring from falls or contact with an object and equipment, and seven each involving vehicles or electrical contact. A more recent publication from the Bureau of Labor Statistics concluded that, on average, there were $58 \mathrm{fa}-$ talities per year in the tree care industry (Wiatrowski 2005). Most fatalities were due to being struck by an object, falls, contact with an electrical conductor, or transportation-related. The latest government report of tree worker accidents found that being struck by or against an object was the most common cause of death, followed by falls then electrocution (Castillo and Menendez 2009). However, there are limitations to these two government reports as they are based upon narrations of accidents investigations and not meant to represent all the fatalities in the industry nor their relative frequency. A study of the logging industry found a significant underestimate of fatalities by the government (Scott 2004), a fact the federal government recognizes (National Institute for Occu- 
pational Safety and Health 1993). Leigh et al. (2004) concluded that the Bureau of Labor Statistics misses between 33\% and 69\% of industrial nonfatal occupational injuries. There is also significant underreporting in their fatality reporting (Azaroff et al. 2002).

A key to improving safety in the tree care profession is to have a better understanding of the current state of safety training as well as the types and frequency of accidents, both fatal and nonfatal. The objectives of this study were to survey tree care company managers on their safety training programs and the types and frequency of accidents that occurred in their company during a five-year period.

\section{METHODS}

A 2007 survey was conducted of the commercial tree care industry in the United States using a mail survey. A company was defined by a business address, meaning a large, regional or national tree company may have each of their offices considered as a company. A total of 775 questionnaires were mailed to tree care companies across the United States.

The companies selected to receive a questionnaire were based on a stratified random sampling (Cochran 1977), with a proportional allocation (Kish 1965), by segmenting the country into regions and city population size. The five geographical regions; northeast, southeast, north-central and western, were identical to that used by other surveys, including a survey of city forestry programs by Gjedraitis and Kielbaso (1982). The number of surveys sent out to each region was almost proportional to their total resident population as provided by the 2000 United States census (Census Bureau 2001). City population was segmented into five categories ranging from cities over one million to cities less than 50,000 populations. Cities were selected proportional to the number in each size category within a region. The final selection of a particular city was from a random selection of cities within a particular category. This proportional allocation procedure was based upon the assumption that the number of tree companies in any region or city was proportional to that of their general population.

Companies sent questionnaires were randomly selected from the local telephone company's Yellow Page line directory of tree care providers for a selected community. Each company was assigned a number and the number selected was taken from the random numbers table in Freese (1962). This selection process created a coverage error of companies that do not advertise, even by a line ad, in their local directory. This may have eliminated some small, one or two-person companies that operate on word-of-mouth and did not advertise in telephone directories. Companies that focus exclusively on utility line clearance work were not included in this survey.

The cover letter, reminders, and survey were constructed following the approach outlined by Dillman (2000). A prenotice letter was sent out a week before the questionnaire to alert company managers to the fact that a questionnaire would soon be arriving and the importance of their prompt response. The questionnaire was sent out with a cover letter again requesting their response. A third contact was made with a reminder card approximately two weeks after the questionnaire was sent out if a response had not been received and this was followed by a final request accompanied by another questionnaire.

The questionnaire content was crafted by following procedures outlined by Dillman (2000) in his Tailored Design Method. The basic design of the questionnaire requires the first questions or section be the ones that would be of most interest to the audience and the final section be devoted to gathering background data on the respondent. The format of each question, regardless of its placement, must be uniform.

Questions regarding accidents were divided into three categories, minor nonfatal, major nonfatal and fatal injuries. We asked for information about accidents that occurred in the company during the past five years (2001-2006). The accidents were divided into the same event or exposure categories utilized by the Bureau of Labor Statistics; transportation incidents, assaults or violent acts, contact with an object and equipment, falls, exposure to a harmful environment or substances and fire. Many of these categories are self-explanatory with the possible exception of "exposure to a harmful environment or substance," where for tree workers contact with electrical conductors is placed. Contact with an object and equipment includes struck by a trees, limb, chain saw, or caught in a chipper.

Additional questions focused on the importance of safety training and what type and frequency of training was conducted within the company. The final section requested background information on the company such as years in business and number of workers.

A total of 534 questionnaires were received, of which 506 were useable for a return rate of $65.4 \%$. Between the mailing of the original questionnaire and the postcard reminder, $32.4 \%$ of the questionnaires were received. Another $49.1 \%$ of the total was received between the mailing of the postcard reminder and the second letter and duplicate questionnaire, and another $18.5 \%$ after the mailing of the duplicate questionnaire. The questionnaires all came within a 76 day time period from the mailing of the original questionnaire. The 28 questionnaires that were received, but were not usable, had sections that were not completed, typically the request for background information on the company, or were returned with a note that the company was no longer in business. Returns were almost proportional to population, with more populous states and regions generating more completed questionnaires than smaller ones. Questionnaires were received from every state except Delaware, Nevada, and Wyoming.

\section{RESULTS}

The median number of field employees in the surveyed companies was 6 with a mean of 10.2 and a range of 1 to 43 . There was mean annual turnover of 1.6 field employees. Approximately half the companies had a gross annual income of less than USD \$500,000. Less than $5 \%$ grossed more than $\$ 2.5$ million annually. The majority of this income was derived from residential tree work, but also some landscaping and lawn care. Approximately $13 \%$ of the companies were members of the Tree Care Industry Association (TCIA).

The need to have trained fieldworkers was identified as "very important" by $87.9 \%$ of the company managers. The remainder indicated that it was somewhat important. This contrasts with the percentage of managers that actually reported any formal training program for their companies. A formal training program is one that has a structured format and curriculum, such as planned monthly safety programs and periodic workshops. Only $62.1 \%$ of the managers indicated that their company had a formal training program for their field workers and only $72 \%$ of these companies trained new workers before placing them in the field.

There are vehicles, machines, and tools used by many tree care companies with the most common being trucks and other vehi- 
cles, such as aerial lifts, chippers, chain saws, and sprayers. Since roughly one-third of the companies surveyed have no formal training program it is not too surprising many workers are using chain saws and chippers with little more than on-the-job training (Table 1). Aerial lift and sprayers are operated more frequently with training while motor vehicle training is relatively rare.

Table 1. The percentage of surveyed commercial tree care companies that provide formal training for the vehicles, machines, and tools utilized in their field work.

\begin{tabular}{ll}
\hline Equipment & Training provided \\
\hline Aerial lift & $77.6 \%$ \\
Chain saws & $59.3 \%$ \\
Chippers & $53.4 \%$ \\
Sprayers & $86.4 \%$ \\
Vehicles & $24.2 \%$ \\
\hline
\end{tabular}

Table 2. The frequency of formal training programs for surveyed tree care companies.

\begin{tabular}{ll}
\hline Training frequency & Percent of companies \\
\hline More than once a month & $5.8 \%$ \\
Once a month & $23.5 \%$ \\
Once every two or three months & $8.6 \%$ \\
Twice a year & $9.6 \%$ \\
Once a year & $7.9 \%$ \\
Less often than once a year & $6.7 \%$ \\
No formal training provided & $37.9 \%$ \\
\hline
\end{tabular}

The most commonly identified training frequency was "none," followed by "once a month" (Table 2). Some respondents wrote on their questionnaire that they considered every day or job a training event, though this cannot be considered formal training. The most common means of providing formal safety training was an employee conducting the training in a field setting (Table 3). These were typically identified as 'tailgate' sessions where a selected topic would be covered in a brief, less than 30-minute time period. The least used training method was utilizing a trainer from outside of the company in a classroom setting.

Aerial rescue procedures had been established for only about $40 \%$ of companies and even fewer practiced aerial rescue (Table 4). Companies that did training in aerial rescue typically practiced climber rescues (Table 5). The majority of companies that did training practiced from a height of 9.1 to $10.6 \mathrm{~m}$ with the goal of bringing the dummy to the ground in less than five minutes. This training was typically performed by an employee in a field setting. Instructors from outside the company were the least likely to be used.

The most common fatal accident involved contact with an energized conductor as a single event (Table 6). However, the event or exposure category with the highest number of fatalities was contact with an object or equipment. No fatalities were identified in two categories: assaults and violent acts, and fire.

Table 3. The method of formal training program delivery for surveyed companies providing instruction to field workers.

\begin{tabular}{ll}
\hline Method most often used to deliver training & Percent of companies \\
\hline In-house trainer in field setting & $66.2 \%$ \\
In-house trainer in classroom setting & $14.3 \%$ \\
Outside trainer in a field setting & $13.0 \%$ \\
Outside trainer in a classroom setting & $6.5 \%$ \\
\hline
\end{tabular}

Table 4. The frequency of aerial rescue training among surveyed companies.

\begin{tabular}{ll}
\hline Training frequency & Percent of companies \\
\hline More than once a month & $0 \%$ \\
Once a month & $5 \%$ \\
Once every two or three months & $0 \%$ \\
Twice a year & $6.9 \%$ \\
Once a year & $14.5 \%$ \\
Less often than once a year & $0.4 \%$ \\
No training & $73.2 \%$ \\
\hline
\end{tabular}

Table 5. The situations and method of delivery for aerial rescue training among companies that provide this instruction to their field workers.

\begin{tabular}{ll}
\hline Situation practiced & Percent of companies \\
\hline Rescue by climber & $52.1 \%$ \\
Rescue by aerial lift operator & $8.6 \%$ \\
Both situations practiced & $39.3 \%$ \\
& \\
Most often used method & Percent of companies \\
of delivering training & \\
\hline In-house trainer in field setting & $65.5 \%$ \\
In-house trainer in classroom setting & $4.7 \%$ \\
Outside trainer in a field setting & $29.1 \%$ \\
Outside trainer in a classroom setting & $0.7 \%$ \\
\hline
\end{tabular}

\section{DISCUSSION}

The Bureau of Labor Statistics (2007) reported there were 55,000 tree trimmers and pruners employed in the United States. They define these workers as individuals who maintain trees for aesthetics or right-of way clearance. This number appears to be is a very low estimation of the number of tree workers. Manta (2007), an internet company and research firm, estimated there are 16,195 tree companies in the United States. Manta also lists the number of tree care companies in each state with the most populous state, California, having the most tree care companies, 1,486; while Alaska had the least, 30 companies. The Manta data did not identify the number of workers. A survey combining tree care with other landscape maintenance and installation services estimated total employment at 514,962 in 76,458 companies (Hall et al. 2007). A recent analysis of companies in the tree care field by O'Bryan et al. (2007) determined there were almost 82,000 in the United States. The O'Bryan et al. study referred to these as establishments rather than companies, however, the definitions used by O'Bryan et al. and the authors of the current study were similar. O'Bryan et al.'s study included 56,394 companies that had a single worker, approximately $68 \%$ of the total number. Only approximately $19 \%$ of the companies in the present survey had two or fewer employees. Small companies, single- or two-person operations, may be less likely to have a Yellow Page advertisement, even a line ad, and would so be missed in this study.

The importance of knowing the number of tree workers is that the Bureau of Labor Statistics provides information on occupational fatalities as ratios of fatalities per 100,000 full-time equivalents. This use of ratios allows for meaningful comparison among occupations employing differing number of workers. For example, the two occupations with the highest number of fatalities in 2008 were commercial fisheries at 50 deaths 
among approximately 38,800 workers, and logging at 82 deaths among an estimated 71,000 workers. This translated to a fatality rate of 128.9 per 100,000 full-time equivalents in fishing, and 115.7 in logging (Bureau of Labor Statistics 2009). The current study of tree care companies identified 42 fatalities over a fiveyear period among approximately 5,160 tree workers. If these fatalities were expanded to an annual fatality rate per 100,000, the ratio would come to 163 fatalities per 100,000 tree workers. This expansion may not be valid considering the sample size, but the ratio is probably close to what is occurring in the field. This does not mean that tree work has the highest fatality rate. The Bureau of Labor Statistics fatality rates for logging, commercial fisheries, and other occupations are probably best considered low estimates as not all the fatalities in these occupations are reported or reported in the correct occupation.

Electrocutions was the single source of most fatalities in this study of tree care businesses; this was also true with two recent government studies (Wiatorwski 2005; Castillo and Menendez 2009), though the highest number of fatal accidents occurred in the event or exposure category "contact with an object and equipment" (Table 5). Taylor et al. (2002) noted that the tree care industry had $35.3 \%$ of the electrocutions across all industries in their survey of fatal occupational electrocutions from 19921999 , a percentage only exceeded by construction at 45.3 percent. They also indicated that the fatality rate from electrocution was 2.36 deaths per 100,000 workers for the tree care industry.

Contact with an object or equipment was the event or exposure category with the highest number of fatalities in the survey, as well as for Wiatorwski (2005) and Castillo and Menendez (2009). Fatalities due to these events are more than four times higher in landscape and horticultural services then all private industries (Buckley et al 2008). These fatalities are spread across a number of events, including contacts involving branches, trees, and chain saws, as well as being caught in a chipper. Castillo and Menendez (2009) indicated there were 38 fatalities involving chippers in the last 15 years among tree workers or about $3 \%$ of all fatal events. Wiatrowski (2005) did not specifically identify chippers in his report, but another report by Struttman (2004) identified 31 occupational deaths involving the use of chippers over an 11-year period. The present survey found that approximately $11 \%$ of all fatalities during the 5 -year reporting period were due to either contact with or being caught in a chipper. While this survey's results are based on fewer fatalities than these cited reports, the data collection methods differed because the data was based on a stratified random sampling of tree care companies while others were based upon reports submitted to the Census of Fatal Occupational Injuries and case studies by the CDC. The government reports may be under estimating the number and frequency of fatal chipper accidents. Ball and Blair (2009) in a paper on fatal chipper accidents highlighted five that occurred in the final two months of 2008. While this may have been an anomaly, if five fatalities could be identified in a two month period then it may be unlikely that only 38 occurred during a 15 -year period.

Neither government study specifically identified chain saws in their survey of fatalities, though Castillo and Menendez (2009) had an injury event called "powered hand tools" that most likely included chain saws. They identified 24 fatalities, or $2 \%$ of the total fatalities in this event category, during the 15 - year reporting period. The present survey had only two deaths attributed to chain saws, or about $5 \%$ of the fatalities reported.

The most common contact fatal accident in the current study was being struck by a falling object, either a limb or a tree. Struck by falling trees and logs are the source of $29 \%$ of all the struck by fatalities in the United States (Personick 1998). Falling branches were the most common source of fatalities due to falling objects in this study, and was second only to electrocutions for the most common fatal event.

The category of falls had the second highest number of total fatalities among all three studies, accounting for approximately one-third of all tree worker fatalities (Table 7). Falls are a common fatal event with this event category, accounting for $9.9 \%$ of all industrial fatal accidents (Bureau of Labor Statistics 1998). The Bureau of Labor Statistics places falls into three groups: falls to a lower level, jumping to a lower level, and falls to the same level. Falls to a lower level are the most common type of occupational fall, typically falling from a roof but falling from a nonmoving vehicle is also common (Webster 2000). The average height of a fatal fall across all industries and age groups is $13.2 \mathrm{~m}$ (Agnew and Suruda 1993). Approximately $4 \%$ of all occupational fatal falls in the United States occur to tree workers, with these involving falls from trees, ladders, and aerial lifts (Webster 2000). Castillo and Menendez (2009) identifies the all tree worker fall fatalities as only to lower levels while Wiatrowski (2005) approximately $8 \%$ of the falls from ladders, the remainder from roofs (1\%) and to a lower level (91\%).

The present study indicates a majority of falls are from a tree, followed by a fall from or with an aerial lift. While the type of aerial lift accident that resulted in a fall was not specifically identified in this study, two of the four did involve equipment failure. Other research has pointed out that falling with a failing lift, rather than from it, is a common source of fatal accidents (Pan et al. 2007). While the survey noted that almost all the companies that provided training, did provide training on the use of this equipment, operator error and

Table 6. Fatal occupation injuries during a five-year period (2001-2006) from a survey of 506 U.S. tree care companies employing a total of approximately 5,150 workers.

\begin{tabular}{ll}
\hline Event & Number of fatalities \\
\hline Transportation incidents & 2 \\
$\quad$ Driving accidents & 0 \\
$\quad$ Struck by vehicle & 0 \\
Assaults and violent acts & \\
& \\
Contact with an object and equipment & 8 \\
$\quad$ Struck-by a limb & 4 \\
$\quad$ Struck-by a tree & 5 \\
$\quad$ Caught in a chipper & 2 \\
$\quad$ Chain saw & \\
Falls $\quad$ From a tree & 7 \\
$\quad$ From an aerial lift & 5 \\
Exposure to harmful substances or environments & \\
$\quad$ Contact with an electrical conductor & 9 \\
Fire & 0 \\
\hline
\end{tabular}


Table 7. Fatal occupational injuries in the tree care profession; a comparison of data with two other studies.

\begin{tabular}{|c|c|c|c|}
\hline Time period & 2001-2006 & 1992-2002 & 1992-2007 \\
\hline $\begin{array}{l}\text { Number } \\
\text { Authors }\end{array}$ & $\mathrm{n}=42$ & $\begin{array}{l}\mathrm{n}=634 \\
\text { (Wiatrowski } \\
\text { 2005) }\end{array}$ & $\begin{array}{l}\mathrm{n}=1,285 \\
\text { (Castillo and } \\
\text { Menendez } \\
\text { 2009) }\end{array}$ \\
\hline Event & \multicolumn{3}{|c|}{ Fatalities as percentages of the total } \\
\hline Transportation incidents & 5 & 12 & 5 \\
\hline Assaults and violent acts & 0 & 1 & 0 \\
\hline $\begin{array}{l}\text { Contact with an object } \\
\text { and equipment }\end{array}$ & 45 & 35 & 46 \\
\hline Falls & 29 & 32 & 34 \\
\hline $\begin{array}{l}\text { Exposure to harmful } \\
\text { substances or environment }\end{array}$ & 21 & 19 & 14 \\
\hline Fire & 0 & 0 & 0 \\
\hline
\end{tabular}

equipment malfunctions do occur and more attention needs to be paid to operation and daily inspection procedures.

The transportation category, while among the lowest in term of fatalities among the three studies, still represented a significant number of fatalities in the tree care industry. All three studies identified highway accidents as the leading cause of fatalities in this category. Unfortunately, training in this aspect of tree care is lacking. The remaining event or exposure categories, "assaults" and "fire," did not have any fatalities appear in the survey, although five assault fatalities were noted by Wistrowski (2005) during a 10-year reporting period. The authors of the present study were not able to find fire fatalities in the tree care industry in any reports regarding tree workers.

\section{CONCLUSION}

Tree work is clearly a high-risk profession, one in which training should be considered essential yet only two-thirds of companies appear to do formal training. This training is primarily conducted by employees within the company. There are limited means of qualifying an employee as a trainer, though TCIA has started a Certified Treecare Safety Professional to provide training in instruction. There also appears to be some gaps in training, with driver's training as the most obvious; and while transportation accidents are not as common as most others, they do result in fatalities, typically highway accidents, and this often neglected area of arborist safety needs to be addressed.

Our study and the two citied government studies of fatal accidents show similar trends with electrical contact being the most common type of fatal accident followed by contact with an object, that object being most often the tree or a portion of it. These three events-electrical contact, and struck by a falling limb or tree-may represent almost half of all the fatalities in the industry. However, the majority of accidents in the tree care profession do not involve a fatality. Part II of this survey will cover nonfatal accidents among tree workers and will also examine the relationship between training to severity and frequency of accidents.

Acknowledgments. This research was partially supported by the TREE Fund Hyland R. Johns grant program. Technical assistance by Aaron Weichmann, former graduate student in Industrial Safety at South Dakota State University, is gratefully acknowledged.

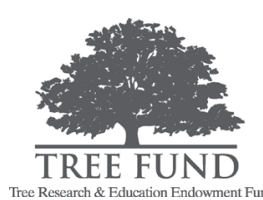

\section{LITERATURE CITED}

Agnew, J., and A. Suruda. 1993. Age and fatal work-related falls. Human Factors 35(4):731-736.

Azaroff, L.S., C. Levenstein, and D. Wegman. 2002. Occupational injury and illness surveillance: conceptual filters explain underreporting. American Journal of Public Health 92:1421-1429.

Ball, J., and D.F. Blair. 2009. Chipper accidents are more common than reported. Tree Care Industry 20(3):8-13.

Blair, D.F. 1989. Safety training for the professional and the non-professional. Journal of Arboriculture 15:209-214.

Buckley, J.P., J.P. Sestito, and K.L. Hunting. 2008. Fatalities in the landscape and horticultural services industry, 1992-2001. American Journal of Industrial Medicine 51:701-713.

Bureau of Labor Statistics. 1998. Fatal workplace injuries in 1996: a collection of data and analysis. U.S. Department of Labor Report 922. U.S. Government Printing Office, Washington, D.C.

Bureau of Labor Statistics. 2007. U.S Department of Labor, Occupational Outlook Handbook 2006-07 edition, Ground Maintenance Workers. Accessed July 31, 2007 <http://www.bls.gov/oco/ocos172.htm>.

Bureau of Labor Statistics. 2009. National census of fatal occupational injuries in 2008. Bureau of Labor Statistics News USDL 09-0979.

Castillo, D.N., and C.K. Menendez. 2009. Work-related fatalities associated with tree care operations - United States, 1992-2007. Morbidity and Mortality Weekly Report 58(15):389-393.

Census Bureau. 2001. County and City Data Book 2000. Accessed September 10, $2006<\mathrm{http}: / / w w w . c e n s u s . g o v /$ prod/www/ccdb.html .

Chadwick, L.C. 1972. The development of a state-wide safety program. Arborist's News 37(2):49-53.

Cochran, W.G. 1977. Sampling Techniques, 3rd Edition. John Wiley \& Sons, New York, NY. 428 pp.

Dillman, D.A. 2000. Mail and Internet Surveys: The Tailored Design Method. John Wiley \& Sons, New York, NY. 464 pp.

Freese, F. 1962. Elementary Foresty Sampling. US Department of Agriculture Agricultural Handbook 232.

Gjedraitis, J.P., and J.J. Kielbaso. 1982. Municipal Tree Management. Urban Data Service Report 14(1):1-4.

Hall, C.R., A.W. Hodges, and J.J. Haydu. 2007. Economic Impacts of the Green Industry in the United States. Southern Cooperative Series Bulletin 406. S-1021/S-290 Multistate Research Project.

Kiplinger, W.C. Tree Surgery. 1938. Michigan Works Progress Administration. Ann Arbor, MI. 226 pp.

Kish, L. 1965. Survey Sampling. John Wiley \& Sons. New York, NY. $641 \mathrm{pp}$.

Kummerling, K. 1948. Safety for the arborist, pg 33-37. In: P. Tilford (Ed.) 24th National Shade Tree Conference Proceedings. Collier Printing Company, Wooster, $\mathrm{OH}$.

Leigh, J.P., J.P. Marcin, and T.R. Miller. 2004. An estimate of the U.S. government's undercount of nonfatal occupational injuries. Journal of Occupational \& Environmental Medicine 46:10-18.

Manta. 2007. Ornamental shrub and tree service companies in the United States. Accessed July 31, 2007. <http://www.manta.com/mb_34_ C030F_000/ornamental_shrub_and_tree services.htm>.

Market Update. 1996. Injuries and fatalities in landscape and horticulture. Grounds Maintenance 31(11):6.

McGarry, G. 1962. Accident prevention methods for the tree industry. Arborist's News 27(8):65-70.

National Institute for Occupational Safety and Health. 1992. Preventing falls and electrocutions during tree trimming. U.S. Dept. Health and Human Services NIOSH publication no. 92-106. 
National Institute for Occupational Safety and Health. 1993. Fatal injuries to workers in the United States, 1980-1989. U. S. Department of Health and Human Services NIOSH publication no. 93-108.

O’Bryan, C.M., T.J. Staka, S.R. Templeton, and J.D. Caldwell. 2007. Economic patterns in U.S. arboriculture. Arboriculture \& Urban Forestry 33:292-299.

O'Connor, W.R. 1989. Tree worker safety. Journal of Arboriculture 15: $17-20$

Pan, S., A. Hoskin, M. McCaan, M. Lin, K. Fearn, and P. Keane. 2007. Aerial lift fall injuries: a surveillance and evaluation approach for targeting prevention activities. Journal of Safety Research 38(6): $617-625$.

Personick, M.E. 1998. Serious injuries befall workers struck by objects. Compensation and working conditions (spring):68-72.

Ryan, H.D.P., and K.A. Ertel. 1988. Arboricultural accidents - cause and control. Journal of Arboriculture 14:70-73.

Scott, D. 2004. A study of logging fatalities from 1992-2000. Injury Prevention 10:239-243.

Shearer, E.C. 1965. Safety in the field of arboriculture. Arborist's News 30(10):75-79.

Struttmann, T.W. 2004. Fatal and nonfatal occupational injuries involving wood chippers- United States, 1992-2002. Morbidity and Mortality Weekly Report 53 (48):31130-1131.

Taylor, A.J., G. McGwin, Jr., F. Valent, and L.W. Rue III. 2002. Fatal occupational electrocutions in the United States. Injury Prevention 8:306-312.

Wiatrowski, W.J. 2005. Fatalities in the ornamental shrub and tree service industry. Bureau of Labor Statistics. Accessed September 15, $2006<w w w . b l s . g o v / o p u b / c w c / s h 200507$ ar01p1.htm>.

Webster, T. 2000. Workplace falls. Compensation and Working Conditions (spring): $28-38$.

\section{John Ball (corresponding author) \\ Professor of Forestry \\ Horticulture, Forestry, Landscape and Parks Department \\ RM 201 Northern Plains Biostress Lab \\ South Dakota State University \\ Brookings, SD 57007, U.S \\ john.ball@sdstate.edu}

Shane Vosberg

Swingles Lawn, Tree and Landscape Care

8585 Warren Avenue

Denver, CO 80231, U.S.

Résumé. Travailler dans un arbre comporte un taux élevé d'accident comparativement à plusieurs autres tâches. Des données sur les accidents récents peuvent facilement être accessibles par l'internet, mais elles ne fournissent pas un portrait véritable du nombre et du type d'accident. Les départements et agences gouvernementales ont produit des rapports citant le nombre et les circonstances des accidents mortels dans la profession. L'information gouvernementale est obtenue de diverses sources et pourrait ne pas identifier avec précision les types ainsi que la fréquence de ces accidents. Un sondage sur ces accidents ainsi que sur les formations à la sécurité parmi les entreprises de services d'arboriculture a été mené au moyen d'un questionnaire via courriel en se basant sur la mé- thode de design de Taylor. Les gestionnaires de compagnies ont répondu à l'enquête en identifiant de manière écrasante qu'avoir des ouvriers formés s'avère très important, et ce même si seulement les deux-tiers d'entre elles menaient elles-mêmes des formations. Les formations les plus fréquemment données étaient sur l'utilisation des nacelles aériennes, des scies mécaniques et des déchiqueteuses à branches, et ces formations étaient données par employés des entreprises sur le terrain. La formation sur la conduite des véhicules ne faisait pas partie du programme formel de sécurité pour la plupart des compagnies. Le sauvetage aérien étai pratiqué par seulement une compagnie sur quatre parmi celles sondées. Les accidents mortels les plus fréquents impliquaient un contact avec un conducteur électrique suivi de celui de la branche en chute libre qui frappe un homme. Le nombre relatif d'accidents mortels par événement ou par exposition identifié dans ce sondage était similaire à celui identifié dans deux rapports gouvernementaux fédéraux concernant les accidents mortels sur le terrain.

Zusammenfassung. Travailler dans un arbre comporte un taux élevé d'accident comparativement à plusieurs autres tâches. Des données sur les accidents récents peuvent facilement être accessibles par l'internet, mais elles ne fournissent pas un portrait véritable du nombre et du type d'accident. Les départements et agences gouvernementales ont produit des rapports citant le nombre et les circonstances des accidents mortels dans la profession. L'information gouvernementale est obtenue de diverses sources et pourrait ne pas identifier avec précision les types ainsi que la fréquence de ces accidents. Un sondage sur ces accidents ainsi que sur les formations à la sécurité parmi les entreprises de services d'arboriculture a été mené au moyen d'un questionnaire via courrie en se basant sur la méthode de design de Taylor. Les gestionnaires de compagnies ont répondu à l'enquête en identifiant de manière écrasante qu'avoir des ouvriers formés s'avère très important, et ce même si seulement les deux-tiers d'entre elles menaient elles-mêmes des formations. Les formations les plus fréquemment données étaient sur l'utilisation des nacelles aériennes, des scies mécaniques et des déchiqueteuses à branches, et ces formations étaient données par employés des entreprises sur le terrain. La formation sur la conduite des véhicules ne faisait pas partie du programme formel de sécurité pour la plupart des compagnies. Le sauvetage aérien était pratiqué par seulement une compagnie sur quatre parmi celles sondées. Les accidents mortels les plus fréquents impliquaient un contact avec un conducteur électrique suivi de celui de la branche en chute libre qui frappe un homme. Le nombre relatif d'accidents mortels par événement ou par exposition identifié dans ce sondage était similaire à celui identifié dans deux rapports gouvernementaux fédéraux concernant les accidents mortels sur le terrain.

Resumen. El trabajo en los árboles tiene una tasa alta de accidentes comparado con otras ocupaciones. Las noticias de accidentes recientes pueden fácilmente conocerse a través de Internet, que da un cuadro del número y tipo de accidentes. Las oficinas y agencias de gobierno pueden producir reportes citando el número y circunstancias de accidentes fatales en la profesión. La información de los gobiernos es obtenida de muchas fuentes y puede no identificar con precisión los tipos y frecuencia de dichos accidentes. Se realizó una encuesta de los accidentes y entrenamiento de seguridad entre compañía de servicios de árboles usando un cuestionario basado en el Método de Diseño Modificado. Los gerentes de las compañías respondieron a la encuesta manifestando contar con personal de campo calificado y entrenado solamente en dos tercios de sus compañías. El entrenamiento más frecuente fue máquinas hidráulicas, motosierras y trituradoras y este entrenamiento fue provisto en el mismo campo. El entrenamiento de los conductores no hizo parte de un programa formal en la mayoría de las compañías. El rescate aéreo fue practicado por cerca de una cuarta parte de las compañías encuestadas. Los accidentes fatales más frecuentes implicaron contactos eléctricos seguidos por golpe de ramas. El número relativo de accidentes fatales por evento fue similar a los identificados por dos reportes federales de accidentes fatales en el campo. 